\title{
STATISTICAL CORRELATIONS BETWEEN THE KNOWLEDGE ECONOMY INDEX AND GENDER (IN)EQUALITY INDEX
}

ŚLĄSKI

PRZEGLĄD

STATYSTYCZNY

Nr 13(19)

\section{Teresa Kupczyk}

University of Business in Wrocław

Wojciech Kordecki

Witelon State University of Applied Sciences in Legnica

DOI: $10.15611 /$ sps.2015.13.03

\begin{abstract}
Summary: The paper attempts to determine statistical correlations between the Knowledge Economy Index (KEI) and the measure of men and women's equali-ty/inequality reflected in the Gender Equality Index. According to the authors' hypothesis such correlations exist. The authors chose the methods of estimation of functional interdependencies between the selected data (KEI, GEI) for the states of the European Union. The analysis confirmed the occurrence of statistically significant positive correlations between the studied indicators, proving that the knowledgebased economy encouraged gender equality. The strongest correlations with the knowledgebased economy were found for such components of the Gender Equality Index as "Time", "Work" and "Knowledge", lesser ones for "Money" and "Health" and the smallest for "Power".
\end{abstract}

Keywords: knowledge-based economy, gender, gender equality.

\section{Introduction}

Although the member states of the European Union guarantee complete gender equality in all aspects of life and work by binding provisions of law, statistical data reveal that equality is not perceived as such. This issue has been present in scientific analyses for years. However, there are not enough in-depth studies of this problem in the environment of the knowledge-based economy. Considering that nowadays it is this economy that is growing the fastest, it is important to diagnose whether it encourages gender equality. This issue has not only social but economic aspects, too, because the greater application of women's potential in the economy, especially considering the global deficiency of talents, as reported by entrepreneurs [Trwa niedobór talentów 2014], is of strategic importance. Therefore the main objective of the paper is to verify the existing correlations between gender equality and a knowledge-based economy based on the Knowledge Economy Index (KEI) and the Gender Equality Index (GEI). The conducted research 
served to verify the hypothesis that there exist such correlations. In the analysis, the authors applied the method of estimation of functional correlations between the selected data of KEI and GEI indices for the member states of the European Union.

\section{Terminology considerations and description of the Gender Equality Index and Knowledge Economy Index}

Gender equality is a complex and multi-dimensional concept, as well as a normatively and politically controversial subject, with a diversity of meanings used across Europe [Verloo and Lombardo 2007]. The European Commission defines gender equality as "the result of the absence of discrimination on the basis of a person's sex in opportunities and the allocation of resources or benefits or in access to services" [The Strategy for equality... 2010].

An expanded definition is provided in the European Commission Women's Charter [A strengthened commitment to equality... 2010] which focuses on the following elements:

- life choices and economic independence;

- the full realisation of women's potential and full use of their skills;

- a better gender distribution in the labour market, more quality jobs for women;

- the promotion of genuine opportunities for both women and men to enjoy a work-life balance;

- human dignity, the right to life and the right to personal integrity.

The Gender Equality Index is based on a simplified overarching definition of gender equality: the equal share of assets and the equal dignity and integrity of women and men [Gender Equality Index, Report 2013, p. 7].

The Gender Equality Index gives a comprehensive map of gender gaps in the EU and across its member states based on the EU policy framework. It aims at:

- providing a synthetic measure of gender equality that is easy to understand and to communicate;

- giving a tailor-made composite indicator measuring gender equality at EU level and within the member states;

- providing a tool to support decision-makers in assessing how far (or close) a given member state is from reaching gender equality; 
- allowing relevant comparisons in different gender equality domains;

- measuring achievements in the area of gender equality over time.

The Gender Equality Index is a tool which can reconcile different STATYSTYCZNY perspectives and definitions of gender equality and adds value to other existing measures of gender equality. It adopts a gender approach that measures gaps between women and men [Gender Equality Index, Main findings... 2013].

The index aims at reconciling different perspectives on gender equality that are present at policy and theoretical levels, including approaches of sameness [Verloo and Lombardo 2007] difference [Walby 2005] and transformation [Walby 2005; Walby 2009]. The conceptual framework of the Gender Equality Index consists of eight domains: the first six (work, money, knowledge, time, power, health) being combined into a core index and an additional two satellite domains (intersecting inequalities and violence). The satellite domains are conceptually related to gender equality, but cannot be included in the core index because they measure an illustrative phenomenon - that is, a phenomenon that only applies to a selected group of the population [Gender Equality Index, Main findings... 2013].

The domain of work also considers how women and men get on in the labour market by analysing the issue of quality of work (participation, segregation, quality of work). The domain of money examines financial resources. This includes pay, earnings and other forms of income, for example social transfers. The domain of knowledge shows the differences between women and men in terms of education and training. The fourth domain of time focuses on the trade-off between economic, care and other social activities (including cultural, civic, etc.). This has not been fully translated into a more equal share of time spent on caring activities. On the contrary, the decreasing differences in time spent on caring activities are due to women's reduced involvement rather than men's greater contribution. As a result, this can translate into fewer opportunities to spend time on other activities, including social, cultural or civic activities [Gender Equality Index, Main findings... 2013].

The domain of power examines how the attainment of gender equality can be affected by women's lack of participation in decisionmaking (for example in economic institutions, including on the boards of the largest quoted companies, political levels, in top positions on scientific boards, as university rectors or in the judiciary, etc.). The last of the core domains is health. It focuses on the differences 
between women and men in terms of health status, behaviour and access to health structures.

The Gender Equality Index relies on the 10-step methodology of building composite indicators developed by the European Commission's Joint Research Centre and the Organisation for Economic Cooperation and Development (OECD) [Nardo et al. 2008].

The analysis of the published opinions confirms that no unequivocal and universally accepted definition of the knowledgebased economy has been developed yet ${ }^{1}$.

As defined by the OECD, this is an economy which relies directly on the production, distribution and application of knowledge and information. In this approach, knowledge is defined as a product and as a factor which drives economic growth [The future of the global economy... 1999]. This is an economy where knowledge is developed, learned, provided and applied more effectively by enterprises, organisations, individuals and communities, contributing to the fast development of the economy and society [Korea and the knowledge based economy... 2000]. According to the definition by the European Commission, such an economy involves the commercial retrieval of new technologies, ideas or methods, which are used to introduce new products and processes or to improve previous ones [Simmie et al. 2002]. In an economy in which the share of labour which applies knowledge intensively is high, the share of information sectors in the economy is a determining factor and the share of intangible assets in the total actual capital is bigger than that of tangible assets [Foray 2004, p. 9]. This is an economy supplied by innovation, technology and talents [Northern Ireland Knowledge Economy Index... 2011].

The most frequently used and seemingly the least controversial definition is the one suggested by international institutions such as the OECD and the World Bank, which have been involved in the measurement of a knowledge-based economy for years. The authors decided to enrich it with the aspect of knowledge as a factor of competitive advantage, as mentioned by [Koźmiński 2001] and other researchers. Consequently, in this paper, a knowledge-based economy is defined as an economy in which knowledge is created, learned, diffused and used more effectively by enterprises which rely on it in their competitive advantage [Kupczyk 2014].

\footnotetext{
${ }^{1}$ In the English language literature the term knowledge-based economy is used, and sometimes the term knowledge economy. Lately, the term k-economy has been used, too [Kefela 2010].
} 
The Knowledge Economy Index (KEI), takes into account whether the environment is conducive for knowledge to be used effectively for economic development. It is an aggregate index that represents the STATYSTYCZNY overall level of development of a country or region towards a Knowledge Economy. The KEI is calculated based on the average of the normalised performance scores of a country or region on all four pillars related to a knowledge economy: economic incentive and institutional regime, education and human resources, the innovation system and ICT.

- An economic and institutional regime to provide incentives for the efficient use of existing and new knowledge and the flourishing of entrepreneurship.

- An educated and skilled population to create, share, and use knowledge well.

- An efficient innovation system of firms, research centres, universities, consultants and other organisations to tap into the growing stock of global knowledge, assimilate and adapt it to local needs, and create new technology.

- Information and communication technology to facilitate the effective creation, dissemination, and processing of information [Chen and Dahlman 2005].

\section{In/equality of women and men vs. knowledge-based economy - current condition}

According to the reports of 2013, the average value of the Gender Equality Index for member states of the European Union (U-27) was 54.0 (the scale: 1 - absolute lack of equality, 100 - complete equality). The best situation was observed in Sweden (74.3), Finland (73.4) and Denmark (73.6). The worst results were those in Bulgaria (37) and Romania (35.3). Poland was ranked as $17^{\text {th }}$ with its score of 44.1, way below the average result for the EU [Gender Equality Index, Country Profiles 2013]. An analysis of particular components of the Gender Equality Index 2013 reveals differences in inequality of women vs. men in various aspects. However, in no aspect has equality been observed. The best situation was revealed in the health aspect. The specific index for this area is composed of: subjective perception of health, expected lifespan at birth, expected healthy lifespan at birth and range of satisfied needs concerning medical and dental care. The indicator for the EU-27 was 90.1, and for Poland - 82.6. It turned out that in the case of Poland, as in other countries of the European Union, this is an area where 
inequalities of women and men are the least. The lowest values of component indicators were noted in the area of "time" (EU - 38.8, Poland - 20.9), which proves that women who work professionally devote significantly more time than men to caring for children or grandchildren, helping them with homework, for housework and cooking. They devote less time to sport, culture, social activities etc. The only exception concerns voluntary activities where the level for both genders is the same. Big differences were also identified for the component indicator of "power" (EU - 38, Poland - 34.5). This element concerns participation in power and decision making, for instance in economic institutions (including boards of the largest companies quoted on the stock exchange), the highest positions in politics, education, science, courts etc. This shows that women in Poland are ministers, members of parliament, members of local governments significantly less frequently than in the rest of the EU. The frequency in the EU and Poland is equal for membership of boards of big corporations, and women in Poland are members of the Central Bank more frequently. However, this situation cannot be described as satisfactory.

The other index we have analysed is the Knowledge Economy Index 2012 (KEI), which described a knowledge-based economy. In this ranking the highest positions are taken by Sweden, Finland and Denmark (Table 1).

Table 1. Knowledge Economy Index 2012 - selected countries and regions.

\begin{tabular}{|r|l|c|c|c|c|c|}
\hline Rate & \multicolumn{1}{|c|}{ Country } & KEI & KI & Innovations & Education & ICT \\
\hline 1 & Sweden & 9.43 & 9.38 & 9.74 & 8.92 & 9.49 \\
\hline 2 & Finland & 9.33 & 9.22 & 9.66 & 8.77 & 9.22 \\
\hline 3 & Denmark & 9.16 & 9.00 & 9.49 & 8.63 & 8.88 \\
\hline 26 & Czech Republic & 8.14 & 8.00 & 7.90 & 8.15 & 7.96 \\
\hline 27 & Hungary & 8.02 & 7.93 & 8.15 & 8.42 & 7.23 \\
\hline 38 & Poland & 7.41 & 7.20 & 7.16 & 7.76 & 6.70 \\
\hline 1 & North America & 8.80 & 8.70 & 9.45 & 8.13 & 8.51 \\
\hline 2 & Europe and Central Asia & 7.47 & 7.64 & 8.28 & 7.13 & 7.50 \\
\hline
\end{tabular}

Source: Knowledge Economy Index KEI 2012, The World Bank.

Poland was ranked $38^{\text {th }}$ out of 146 countries. Better scores were also observed for Germany (8), USA (12), Czech Republic (26) or Hungary (27). As compared to 2000, Poland's position fell by three ranks while the Czech Republic, Hungary and Romania improved their scores. Internationally, Poland is ranked $37^{\text {th }}$ according to the "knowledge" indicator, while for the "education and human capital" 
indicator $-24^{\text {th }}$. This is not a dramatic result, especially in relation to the population of people aged 15-64 with a university degree. However, Poland's position is worse in the case of innovations (7.16) STATYSTYCZNY and the application of information and communication technologies (6.70) [Knowledge Economy Index 2012] ${ }^{2}$.

\section{Methods}

A detailed description of methodology of calculating GEI is described in the report [Gender Equality Index, Report 2013]. Data in Table 1 originates from [Gender Equality Index, Country Profiles 2013]. Here,

Table 2. Values of GEI, KEI indices and the components: W - Work, $\mathrm{M}$ - Money, $\mathrm{K}$ Knowledge, $\mathrm{T}$ - Time $\mathrm{P}$ - Power, $\mathrm{H}$ - Health. Countries were sorted from the highest GEI.

\begin{tabular}{|c|c|c|c|c|c|c|c|c|c|c|}
\hline & Symbol & Country & GEI & $\begin{array}{c}\mathrm{W} \\
(1)\end{array}$ & $\begin{array}{c}M \\
(2)\end{array}$ & $\begin{array}{c}\mathrm{K} \\
\text { (3) }\end{array}$ & $\begin{array}{c}\mathrm{T} \\
(4)\end{array}$ & $\begin{array}{c}\mathrm{P} \\
(5)\end{array}$ & $\begin{array}{c}\mathrm{H} \\
(6)\end{array}$ & KEI \\
\hline 1 & SE & Sweden & 74.3 & 78.6 & 80.2 & 66.3 & 63.9 & 74.3 & 93.1 & 9.43 \\
\hline 2 & DK & Denmark & 73.6 & 81.6 & 79.2 & 75.1 & 64.9 & 60.0 & 91.8 & 9.16 \\
\hline 3 & FI & Finland & 73.4 & 82.0 & 78.4 & 67.0 & 63.8 & 68.8 & 89.9 & 9.33 \\
\hline 4 & NL & Netherlands & 69.7 & 73.1 & 82.5 & 65.5 & 71.3 & 52.2 & 94.7 & 9.11 \\
\hline 5 & UK & United Kingdom & 60.4 & 76.6 & 74.3 & 68.8 & 43.2 & 35.2 & 95.4 & 8.76 \\
\hline 6 & $\mathrm{BE}$ & Belgium & 59.6 & 66.4 & 79.3 & 54.7 & 45.3 & 45.2 & 94.1 & 8.71 \\
\hline 7 & FR & France & 57.1 & 67.0 & 75.9 & 49.4 & 35.8 & 50.3 & 90.6 & 8.21 \\
\hline 8 & SI & Slovenia & 56.0 & 69.1 & 70.2 & 51.4 & 49.1 & 36.0 & 88.7 & 8.01 \\
\hline 9 & IE & Ireland & 55.2 & 71.0 & 77.0 & 52.8 & 53.4 & 26.5 & 96.4 & 8.86 \\
\hline 10 & ES & Spain & 54.0 & 61.3 & 60.7 & 53.5 & 33.8 & 47.2 & 90.7 & 8.35 \\
\hline 11 & $\mathrm{DE}$ & Germany & 51.6 & 72.5 & 76.3 & 44.1 & 41.6 & 28.0 & 89.5 & 8.9 \\
\hline 12 & LU & Luxembourg & 50.7 & 66.4 & 90.9 & 61.1 & 48.9 & 14.7 & 93.9 & 8.37 \\
\hline 13 & AT & Austria & 50.4 & 73.9 & 77.9 & 44.6 & 40.0 & 24.3 & 91.6 & 8.61 \\
\hline 14 & $\mathrm{EE}$ & Estonia & 50.0 & 64.6 & 49.1 & 53.0 & 51.4 & 27.5 & 83.8 & 8.4 \\
\hline 15 & $\mathrm{CZ}$ & Czech Republic & 44.4 & 71.6 & 59.3 & 37.3 & 23.2 & 29.6 & 89.6 & 8.14 \\
\hline 16 & LV & Latvia & 44.4 & 54.9 & 42.0 & 38.8 & 35.2 & 38.6 & 77.1 & 7.41 \\
\hline 17 & PL & Poland & 44.1 & 61.4 & 52.2 & 44.0 & 20.9 & 34.5 & 82.6 & 7.41 \\
\hline 18 & LT & Lithuania & 43.6 & 61.0 & 41.5 & 47.4 & 24.1 & 32.1 & 84.9 & 7.8 \\
\hline 19 & $\mathrm{CY}$ & Cyprus & 42.0 & 68.7 & 74.1 & 52.9 & 25.3 & 12.2 & 91.1 & 7.56 \\
\hline 20 & MT & Malta & 41.6 & 55.0 & 68.2 & 34.0 & 37.5 & 18.7 & 93.2 & 7.88 \\
\hline 21 & $\mathrm{HU}$ & Hungary & 41.4 & 55.9 & 54.4 & 35.1 & 32.5 & 24.4 & 83.7 & 8.02 \\
\hline 22 & $\mathrm{PT}$ & Portugal & 41.3 & 66.2 & 56.3 & 30.4 & 22.4 & 30.6 & 84.5 & 7.61 \\
\hline 23 & SK & Italy & 40.9 & 60.6 & 68.2 & 32.1 & 33.0 & 18.6 & 90.8 & 7.89 \\
\hline 24 & IT & Slovakia & 40.9 & 61.0 & 53.7 & 35.0 & 17.8 & 33.1 & 85.8 & 7.64 \\
\hline 25 & EL & Greece & 40.0 & 59.7 & 63.3 & 36.7 & 17.4 & 24.4 & 92.4 & 7.51 \\
\hline 26 & $\mathrm{BG}$ & Bulgaria & 37.0 & 49.9 & 40.7 & 32.0 & 17.3 & 33.8 & 84.5 & 6.8 \\
\hline 27 & $\mathrm{RO}$ & Romania & 35.3 & 60.4 & 39.0 & 28.8 & 17.8 & 24.9 & 84.0 & 6.82 \\
\hline
\end{tabular}

Source: own elaborations.

${ }^{2}$ KAM 2012 KAM methodology and value of KEI, KI indices (2012) are described on the website: http://info.worldbank.org/etools/kam2/KAM_page5.asp. 
Table 2 will present only the GEI index (column 3), components of this index (columns 4-8) and the KEI index (column 9). Most calculations for this paper were made with the symbolic computation software Maxima ${ }^{3}$.

As can be expected, there is a strong linear dependence between GEI and KEI

$$
y=0.0554 x+5.3552,
$$

where $y$ is the value of KEI, and $x$ is the value of GEI. The correlation coefficient is $\rho=0.8931$.

It seemed interesting to analyse the correlations between the structure of GEI and KEI value, as the same or similar value of GEI may correspond to various values of $[W, M, K, T, P, H]$ vectors. For instance, the GEI value of 44.4 is identical for the Czech Republic and Latvia. The $M$ component for the Czech Republic is more than 1.4 times higher than in Latvia, while the $T$ component is less than a half of its equivalent for Latvia. These correlations between the $[W, M, K, T, P, H]$ components and KEI are shown in Table 3.

Table 3. Correlations between GEI, its $[W, M, K, T, P, H]$ components and KEI

\begin{tabular}{|c|c|c|c|c|c|c|c|}
\hline Factor & GEI & $\mathrm{W}$ & $\mathrm{M}$ & $\mathrm{K}$ & $\mathrm{T}$ & $\mathrm{P}$ & $\mathrm{H}$ \\
\hline Correlation & 0.8931 & 0.8230 & 0.7666 & 0.7977 & 0.8755 & 0.5736 & 0.6317 \\
\hline
\end{tabular}

Source: own elaborations.

Therefore it would be interesting to verify the correlations of proximity of GEI values and their structural similarity, as well as the correlations between the proximity of KEI values and GEI structure. The proximity (similarity) of the GEI indices' structure will be described by the Euclidean distance with the following formula

$$
d\left(I_{j}, I_{k}\right)=\sqrt{\sum_{i=1}^{6}\left(x_{j, i}-x_{k, i}\right)^{2}},
$$

where $x_{j, i}$ is the value of the GEI $i^{\text {th }}$ component for the $j^{\text {th }}$ country according to numbers in Table 2 . The distance $d=0$ signifies identical components, so a low $d$ value reflects the proximity or similarity of GEI structures.

\footnotetext{
${ }^{3}$ Software available at http://maxima.sourceforge.net/ by GNU licence.
} 
We tried to reduce the countries to a small group of countries which are similar according to $d$ distance estimated according to formula (2). To do so, we applied the divisive method of cluster STATYSTYCZNY analysis. We used the convenient and well known method of Wroclaw taxonomy [Florek et al. 1951], re-discovered many years later (an example paper [Gower and Ross 1969] and monograph [Anderberg 1973]).

The method of elements' grouping in Wrocław taxonomy involves finding a minimal spanning tree (a tree of minimal sum of the weights of its edges) in a complete graph where the apices are the grouped elements and the edges' weights are the distances between the elements. Next, from the resultant minimal tree we removed the edges from the largest to the smallest weight, obtaining subsequent sub-trees of the initial trees. The apices of these sub-trees correspond to the elements' groups achieved at subsequent stages of division. The algorithms of finding minimal trees are greedy algorithms, so they are very efficient (cf. [Cormen et al. 2009], section 23) and they are implemented in multiple editions of mathematical symbolic computation software ${ }^{4}$.

Here, the graph's apices are countries and the distance which represents the dissimilarity of $[W, M, K, T, P, H]$ structures of GEI for particular countries is estimated according to formula (2). Zero dissimilarity signifies the identical structure of GEI index, while a big $d$ distance means the high dissimilarity or low similarity of GEI structures.

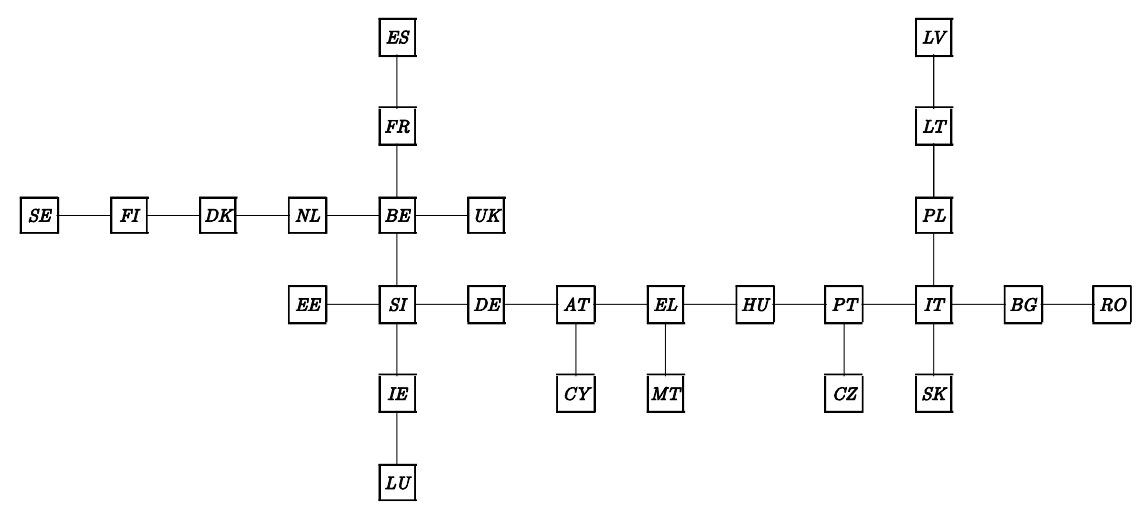

Figure 1. Minimal tree for countries with distances defined by formula (2).

Source: own elaborations.

\footnotetext{
${ }^{4}$ Here, we applied the minimum_spanning_tree procedure of Maxima software.
} 
We selected a couple of countries with the lowest $d$ distance, then another couple of the next lowest $d$ distance, excluding however those couples of countries which are joined by the chain of the previously selected country pairs. As a result, we obtain the minimal tree shown in Figure 1.

The obtained weight (distance) values are shown in Table 4 in decreasing sequence according to the tree shown in Figure 1. For comparison, two columns on the right present differences of GEI and KEI indices for edges of the minimal tree corresponding to the couples of countries.

Table 4. Weight (distance) values in minimal spanning tree and differences in GEI and KEI

\begin{tabular}{|ll|c|c|c|}
\hline \multirow{2}{*}{ Pairs of countries } & distance & difference in GEI & difference in KEI \\
\cline { 3 - 5 } & & $(1)$ & $(2)$ & $(3)$ \\
\hline NL & BE & 29.95 & 0.40 & 10.10 \\
\hline SI & EE & 23.87 & 0.39 & 6.00 \\
\hline AT & EL & 22.57 & 1.10 & 10.40 \\
\hline AT & CY & 21.75 & 1.05 & 8.40 \\
\hline IE & LU & 21.19 & 0.56 & 4.50 \\
\hline UK & BE & 20.83 & 0.05 & 0.80 \\
\hline LV & LT & 18.38 & 0.39 & 0.80 \\
\hline HU & EL & 17.49 & 0.51 & 1.40 \\
\hline IT & BG & 17.43 & 1.09 & 3.90 \\
\hline FR & ES & 17.15 & 0.14 & 3.10 \\
\hline DK & NL & 16.90 & 0.05 & 3.90 \\
\hline HU & PT & 16.52 & 0.41 & 0.10 \\
\hline BE & SI & 15.14 & 0.70 & 3.60 \\
\hline SI & DE & 14.93 & 0.89 & 4.40 \\
\hline SI & IE & 14.83 & 0.85 & 0.80 \\
\hline IT & SK & 14.70 & 0.25 & 0.00 \\
\hline BG & RO & 14.25 & 0.02 & 1.70 \\
\hline BE & FR & 12.98 & 0.50 & 2.50 \\
\hline DK & FI & 12.19 & 0.17 & 0.20 \\
\hline PL & LT & 12.14 & 0.39 & 0.50 \\
\hline CZ & PT & 10.65 & 0.53 & 3.10 \\
\hline PL & IT & 10.26 & 0.48 & 0.40 \\
\hline PT & IT & 9.17 & 0.28 & 1.60 \\
\hline MT & EL & 7.81 & 0.37 & 0.10 \\
\hline SE & FI & 7.47 & 0.29 & \\
\hline DE & AT & 5.04 & & \\
\hline & & & & \\
\hline
\end{tabular}

Source: own elaborations. 
As shown, countries which are close for their (2) results and make a pair in the tree in Figure 1, are not proximal with respect to the differences of the GEI and KEI indices. On the contrary, countries STATYSTYCZNY which are proximal with respect to the GEI difference (or even identical, as in the case of the Czech Republic and Latvia) are not close with respect to (2) result, where the difference is 31.02 . Similarly for KEI. Poland and Latvia have an identical KEI value of 7.41. Meanwhile, the distance of (2) result is 20.6126.

The above remarks also explain the observed fact that the correlation between the GEI and KEI indices is larger (often significantly larger) than the correlations between the KEI result and components of GEI.

Therefore it would be interesting to compare the correlations between the proximities of the countries which are in the minimal tree and the differences between their GEI and KEI indices which are given in the column (1)-(3). The respective correlation coefficients are as follows:

Correlation between (1) and (2):

$$
\begin{aligned}
& \rho=0.2731 \\
& \rho=0.6850 \\
& \rho=0.5299
\end{aligned}
$$

Correlation between (1) and (3):

Correlation between (2) and (3):

In other words, the similarities between countries when considering the differences of GEI value and similarities between countries when considering (2) distances, are of a significantly different structure.

Next, we analysed the process of country grouping based on the criterion of similarities of the structure of GEI index. By removing the edge of the largest weight from the minimal tree, that is the (BE,NL) pair, we obtained a division between Sweden, Finland, Denmark, the Netherlands and other countries. The removal of the next edge (SI,EE) pair results in the separation of Estonia. The removal of another pair (AT,EL) brought a division into further two groups.

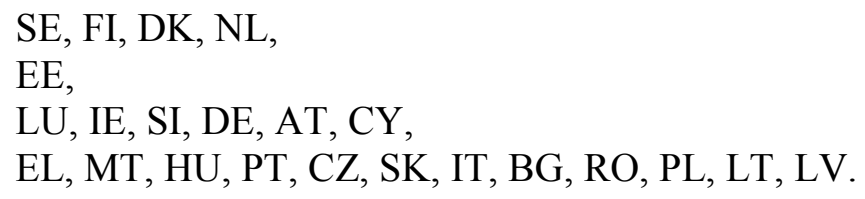




\section{ŚLĄSKI \\ PRZEGLĄD \\ STATYSTYCZNY \\ 5. Conclusions \\ Nr 13(19)}

The presented analyses permit a conclusion that nowadays there is no equality of women and men in any state of the European Union for such areas as "Work", "Knowledge", "Money", "Health" and "Power". This is worrying not just because of social justice, but also for economic aspects, as the higher participation of women on the labour market and in management and decision-making may become a good solution to soothe demographic problems, as well as modern deficiencies of the supply of relevant candidates for many posts, including top management positions. However, this does not affect the fact that the question whether and when women and men will achieve equal opportunities still remains unanswered. Furthermore, this fact should encourage a discussion about the efficiency of efforts taken by the European Union in this area over the last decade, especially considering the financial resources allocated to this objective.

The results of the study suggest the acceptance of the hypothesis as right. Therefore, there are positive, statistically significant correlations between the knowledge-based economy according to the Knowledge Economy Index (KEI) and the degree of equality of women and men as reflected in the Gender Equality Index. It seems justified to conclude that the more knowledge-based the economy is, the larger the gender equality. The strongest correlation with the knowledge-based economy was found for such components of the Gender Equality Index as "Time", then "Work" and "Knowledge", and the weakest correlations for "Money", "Health" and "Power". It should be added that all those correlations were very strong. The overall conclusion is that a knowledge-based economy encourages more equal chances for women and men.

In this context, the authors have developed the following postulates.

- Efforts to provide equal chances for both sexes should be continued.

- Definitelyly, mechanisms to make it easier to reconcile family and professional roles should be improved in number and effectiveness, e.g. by promoting flexible employment and the shared care of children, especially when the children are sick (alternation of sick leaves for the mother and father).

- Gender-related differences in pay should be levelled by special strategies combining all available instruments, including legal provisions. 
- Effort should be made to promote and to impact on the participation of women in top management in the economy, $\mathrm{Nr}$ 13(19) administration, science and politics.

- More government programmes should be aimed at women to support them in life and on the labour market.

- Achieving gender equality should become the main objective, as it will permit the building of a better functioning and wealthier state. The involvement of women in professional, social and political life is an immense potential which should not be wasted.

\section{References}

A strengthened commitment to equality between women and men, The European Commission Women's Charter 2010.

Anderberg M.R. Cluster analysis for applications, Academic Press, New York 1973.

Chen D.H.C., Dahlman C.J., The knowledge economy, the KAM methodology and World Bank Operations, World Bank Institute, 2005, Working Paper no. 37256 (on-line), papers.ssrn.com/sol3/papers.cfm?abstract_id=841625.

Cormen T.H., Leiserson C.E., Rivest R.L., Stein C. Introduction to Algorithms, The MIT Press, 3rd edition, 2009.

Florek K., Łukaszewicz J., Perkal J., Steinhaus H., Zubrzycki S., Sur le liaison et la decision des points d'un ensemble fini, „Colloqium Mathematicum” 1951, Vol. II (3-4).

Foray D. The economics of knowledge, MIT Press, Cambridge 2004.

Gender Equality Index, Country Profiles, The European Institute for Gender Equality, Report 2013.

Gender Equality Index, Main findings of The European Institute for Gender Equality, Report 2013.

Gender Equality Index, Report, The European Institute for Gender Equality, Report 2013.

Gower J.C. and Ross G. J. S. Minimum spanning trees and single linkage cluster analysis, "Journal of the Royal Statistical Society" Series C (Applied Statistics), 1969, Vol. 180(1), pp. 54-64.

Kefela G.T. Knowledge-based economy and society has become a vital commodity to countries. "International Journal of Educational Research and Technology" 2010, Vol. 1(2), pp. 68-75.

Knowledge Economy Index, The World Bank 2012.

Korea and the knowledge based economy, Making the transition. OECD - The World Bank Institute 2000.

Koźmiński A.K. Jak stworzyć gospodarkę oparta na wiedzy?, [In:] Strategia rozwoju Polski u progu XXI wieku. Kancelaria Prezydenta RP i Komitet Prognoz „Polska 2000 Plus" PAN, Warszawa 2001.

Kupczyk T., Competencies of management staff in the knowledge-based economy, Wyższa Szkoła Handlowa, Wrocław 2014.

Nardo M., Saisana M., Saltelli A., Tarantola S., Hoffman A., Giovannini E., Handbook on constructing composite indicators: Methodology and user guide, OECD, European Commission, Joint Research Centre 2008.

Northern Ireland Knowledge Economy Index, Baseline Report 2011, Oxford Economics for Northern Ireland Science Park, Northern Bank 2011. 
Simmie J., Sennett J., Wood P., Hart D. Innovation in Europe: A tale of networks, knowledge and trade in five cities, "Regional Studies" 2002, Vol. 36(1), pp. 47-64.

Nr 13(19)

The future of the global economy. Towards a long boom?, OECD 1999.

The Strategy for equality between women and men represents the European Commission's work program on gender equality for the period 2010-2015, 21.9.2010(COM(2010)91 final), 2010.

Trwa niedobór talentów, MenpowerGroup 2014.

Verloo M., Lombardo E., Contested gender equality and policy variety in Europe. Introducing a critical frame analysis approach, [in:] Verloo M. (ed.), Multiple Meanings of Gender Equality. A critical frame analysis of gender policies in Europe, chapter I, Central European University Press 2007.

Walby S., Gender mainstreaming: Productive tensions in theory and practice, "Social Politics"' 2005, Vol. 12(3), pp. 321-343.

Walby S., Beyond the politics of location: the power of argument in gender equality politics, [in:] Verloo M., Lombardo E., Meier P. (ed.), The Discursive Politics of Gender Equality: Stretching, Bending and Policymaking, Routledge 2009, pp. 36-51.

\section{STATYSTYCZNE ZWIĄZKI POMIĘDZY WSKAŹNIKIEM GOSPODARKI OPARTEJ NA WIEDZY (KNOWLEDGE ECONOMY INDEX) A STOPNIEM NIE/RÓWNOŚCI KOBIET I MĘŻCZYZN (GENDER EQUALITY INDEX)}

Streszczenie: W opracowaniu podjęto się ustalenia statystycznych związków pomiędzy wskaźnikiem gospodarki opartej na wiedzy według Knowledge Economy Index (KEI) a stopniem nie/równości kobiet i mężczyzn zgodnie z Gender Equality Index. Autorzy opracowania stawiają hipotezę, mówiącą o tym, iż takie związki istnieją. Dokonano wyboru metod estymacji funkcyjnych zależności pomiędzy wybranymi danymi (KEI, GEI) dla krajów Unii Europejskiej. Przeprowadzona analiza potwierdziła istnienie dodatnich istotnych statystycznie korelacji między badanymi wskaźnikami, co dowodzi, iż gospodarka oparta na wiedzy sprzyja równości kobiet i mężczyzn. Najsilniej z gospodarką opartą na wiedzy korelują takie składowe wskaźnika Gender Equality Index, jak „Czas”, „Praca” i „Wiedza”, w mniejszym stopniu „Pieniądze” i „Zdrowie”, w najmniejszym ,Władza”.

Słowa kluczowe: gospodarka oparta na wiedzy, zarządzanie, gender, równość kobiet i mężczyzn. 